\title{
Appendiceal Carcinoma pT2 TNM Finding v8
}

National Cancer Institute

\section{Source}

National Cancer Institute. Appendiceal Carcinoma pT2 TNM Finding v8. NCI Thesaurus. Code C134098.

Appendiceal carcinoma with tumor invading the muscularis propria. (from AJCC 8th Ed.) 